\title{
3D modelling of coal seams for optimization of extraction
}

\author{
Ábel Dániel Antonovits ${ }^{1 *}$, and József Molnár ${ }^{1}$ \\ ${ }^{1}$ Institute of Mining and Geotechnical Engineering, University of Miskolc, Miskolc-Egyetemváros, \\ Hungary
}

\begin{abstract}
Underground coal mining was finished in the north-eastern region of Hungary after its operation of more than two centuries, as a result of economic, technical, environmental and political reasons. A fairly significant part of the reserve is still available to extract. With a different perspective of coal mining, considering different ways of utilization (such as coal chemistry, etc.) the extraction of the material can still be cost effective. In the past few years, several studies were conducted regarding the possible utilization of the available reserve. The properties of the coal are highly mutable, therefore, comprehensive knowledge about the geology is indispensable. Two and three-dimensional modelling of the coal seam is discussed in this paper, with the optimal coal face height, and the expected quality of mining products taken into consideration. Applying the method presented, the production can fulfil the desired properties, regarding to the utilization of the coal.
\end{abstract}

\section{Introduction}

In the field of mining, one of the main possible goal of modelling, is the systematization of the available information from the exploration, thereby, contribute to the characterization of technological parameters, and support the preparation of technological decisions trough the mining phase [1]. In this paper, we present a way of modeling trough the Dubicsány brown coal deposit, located in north-eastern part of Hungary.

\section{Dataset}

The initial dataset consists of 252 boreholes. The core samples, taken from the boreholes, were divided in every $0,1 \mathrm{~m}$. For these samples, ash content, moisture content, calorific value, heat of combustion, fixed carbon, -hydrogen and combustible sulfur content were determined, all of which were used for the two- and three-dimensional modeling of the deposit.

The basic map and the characterization of the area was carried out in previous studies [2, 3 ]. By updating the method of computation for the above mentioned quality parameters, with

\footnotetext{
* Corresponding author: bgtabel@uni-miskolc.hu
} 
a new algorithm, it is possible to make an advanced model, in which we can ensure the quality requirements for the further use, with considering the available mining technology.

The prior studies [4-6] identified some basic rules of coal mining in the region. Related to our study, one needs to be noted. In this hazardous environment, to prevent water and mud inrush, on the roof of the excavations, the top approximately $0,3 \mathrm{~m}$ thick layer of the coal, is not intended to be mined out for safety reasons.

\section{The algorithm}

The method is based on various inputs, which can be required quality, quantity or technologyrelated parameters. In this paper, we will present a case, where the underground coal mine required to produce an average minimal calorific value and the technology define an extractable minimal and maximal height value of the coal face, using the previously introduced dataset.

\subsection{Minimal thickness}

The minimal thickness $\left(\mathrm{h}_{\min }\right)$, which is one of the input parameters, is the smallest extractable slice thickness, measured from the bottom of the $0,3 \mathrm{~m}$ thick layer. In those cases, where the vertical thickness of the sample cannot reach the specified minimal thickness, in order to avoid the need to cut inert material from the bed, the extractable thickness was taken as zero.

$$
h_{\min , x}=\left\{\begin{array}{ccc}
h_{\min }, & \text { if } \quad h \geq h_{\min } \\
0 & \text { otherwise }
\end{array}\right.
$$

where

$\mathrm{h}_{\mathrm{min}, \mathrm{x}}$ - the thickness calculated from the minimal thickness [m]

$\mathrm{h}_{\min }$ - the minimal thickness [m]

$\mathrm{h}$ - thickness of the coal at the given drilling point $[\mathrm{m}]$

\subsection{Maximal thickness}

The second input parameter, the maximal thickness $\left(\mathrm{h}_{\max }\right)$, is the possible maximum of the extractable slice thickness, measured from the bottom of the $0,3 \mathrm{~m}$ thick layer. If the thickness of all vertical samples are greater than the specified maximal slice thickness, the maximal slice thickness is considered. In those cases, where the vertical thickness of the sample is less than the specified maximal thickness, the measured slice thickness is taken into account, if it also satisfies the conditions for the minimal slice thickness.

$$
h_{\max , x}=\left\{\begin{array}{ccccc}
h_{\max }, & \text { if } & h \geq h_{\max } & \text { and } & h_{\min , x} \neq 0 \\
h, & \text { if } & h<h_{\max } & \text { and } & h_{\min , x} \neq 0 \\
h_{i}, & \text { if } & Q_{i} \leq Q_{\min } & \text { and } & h_{\min , x} \neq 0 \\
0 & \text { otherwise } & & &
\end{array}\right.
$$

where

$\mathrm{h}_{\max , \mathrm{x}}$ - the thickness calculated from the input parameters[m]

$\mathrm{h}_{\max }$ - the maximal thickness (input parameter) [m]

$\mathrm{h}_{\mathrm{qi}}, \mathrm{Q}_{\mathrm{i}}$ and $\mathrm{Q}_{\min }$ will be defined in the next chapter 


\subsection{Expected minimal calorific value}

The expected minimal calorific value $\left(\mathrm{Q}_{\mathrm{min}}\right)$ is the average calorific value of the coal you must reach at the given point (borehole). The algorithm determines, considering all input parameters, the average calorific value of the extractable coal. The heat content of the vertical samples is summed from above, until the calculated average calorific value reach the prespecified value. Since in our case, the calorific value decreases vertically, those cases, when the calorific value changes in a wave-like manner, do not have to be considered. It is important to note, that this method does not specify the slice thickness at the sample thickness, when the slice thickness corresponding to the given parameters is limited by the calorific value, however the quality parameters of the last sample are considered to be equal through the whole thickness of the sample.

The first step is to consider the calorific values:

$$
Q_{\text {min }, x}=\left\{\begin{array}{cc}
Q, & \text { if } \quad Q \geq Q_{\text {min }} \\
0 & \text { otherwise }
\end{array}\right.
$$

where

$\mathrm{Q}_{\min , \mathrm{x}}$ - the average calorific value calculated from the input parameters $\left[\frac{\mathrm{MJ}}{\mathrm{kg}}\right]$

$\mathrm{Q}$ - the average calorific value calculated at the given drilling point at $\mathrm{h}_{\max , \mathrm{x}}\left[\frac{\mathrm{MJ}}{\mathrm{kg}}\right]$

In the determination of $\mathrm{Q}$, we distinguish two cases, depending on which parameter limits the average calorific value of the extractable coal.

\subsubsection{The coal face height is the limit}

If the quality meets the expectations at the given point and the thickness should be reduced due to the maximal thickness, the extractable average calorific value will be equal to the average calorific value calculated at the depth of the maximal thickness.

$$
Q=\left\{\begin{array}{cc}
Q_{x}, & \text { if } \quad \\
0 & \text { otherwise }
\end{array} Q_{x} \geq Q_{\min } \text { and } \quad h_{\max , x} \neq 0\right.
$$

where

$\mathrm{Q}_{\mathrm{x}}$ - the average calorific value at the previously determined (thickness calculations) lowest point of the coal layer $\left(\mathrm{h}_{\max }\right)\left[\frac{\mathrm{MJ}}{\mathrm{kg}}\right]$

\subsubsection{The expected minimal calorific value is the limit}

When the average calorific value at the depth of the maximal thickness does not meet the requirements, it will be equal to the expected minimal calorific value. It means, that the expectation can be provided with a smaller slice thickness, therefore, the slice thickness of the extractable material will be reduced.

$$
Q=\left\{\begin{array}{cc}
Q_{\min }, & \text { if } \quad Q_{i} \leq Q_{\min } \quad \text { and } \quad h_{\min } \leq h_{i} \leq h_{\max } \\
0 & \text { otherwise }
\end{array}\right.
$$


where

$\mathrm{Q}_{\mathrm{i}}$ - the average calorific value at $\mathrm{h}_{\mathrm{i}}$ thickness $\left[\frac{\mathrm{MJ}}{\mathrm{kg}}\right]$

$\mathrm{h}_{\mathrm{qi}}-$ the thickness, where the average calorific value is equal to the expected minimal calorific value $[\mathrm{m}]$

\section{Results}

With the above presented method, the available calorific value and the thickness of the extractable coal at each drilling point can be determined, considering the minimal thickness, the maximal thickness and the expected minimal calorific value.

Beside the two and three dimensional display of the reserve, another possible application of the method can be seen at figure 1, where the thickness of extractable coal is showed as a function of the average calorific value.

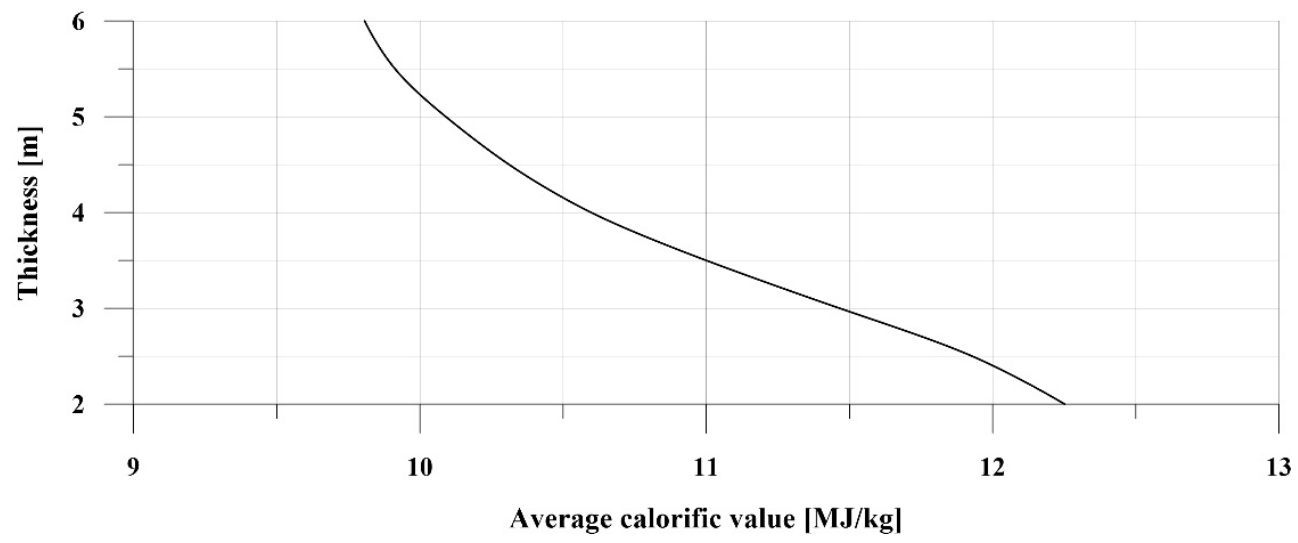

Fig. 1. Thickness, as a function of the average calorific value.

If it is required, the method can be applied to other parameters also, for example sulphur content figure 2 , or weight of extractable raw material figure 3.

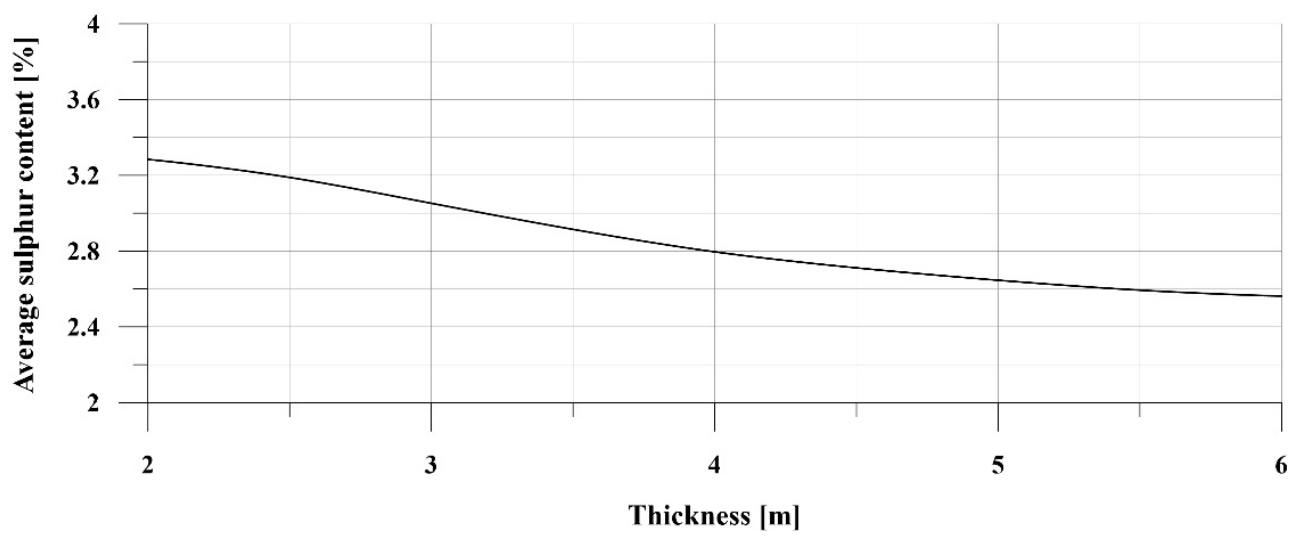

Fig. 2. Average sulphur content, as a function of the thickness. 


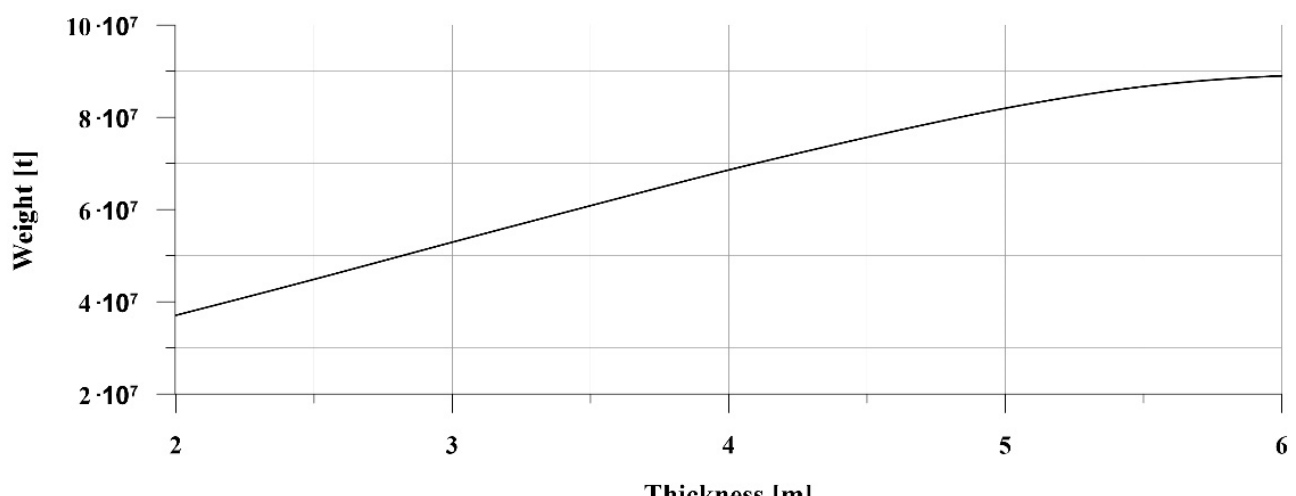

Fig. 3. Weight, as a function of the thickness.

\section{Conclusion}

The modelling of raw material reserves has a crucial significance in the planning of mining operations. By the application of the presented method, the amount of extractable material can be calculated, taking the desired quality parameters, and the expected mining method into consideration. The process, which can be used to other mineral deposits, also enables to determine the correlation between the examined parameters.

\section{References}

1. J. Molnár, Á. D. Antonovits, V. Mádai, Z. Virág: A dubicsányi barnakőszén lelőhely V. telepének 3D (térbeli) modellezése a bányászat koncepcionális tervezéséhez, Miskolci Egyetem, research report, 78 p. (2020)

2. A dubicsányi barnakőszén előfordulás geometriai és minőségi adottságainak háromdimenziós modellezése, a gazdaságosan kitermelhető vagyon mennyiségének és minőségének újraértékelése, research report, Miskolci Egyetem, Bányászati és Geotechnikai Intézet (2018)

3. J. Molnár, Á. Debreczeni, R. Tompa: Challanges and Opportunities of Underground Coal Mining in Northeastern Hungary, Universitaria SIMPRO 2018, $8^{\text {th }}$ International Multidisciplinary Scientific Symposium, Conference proceedings p 347-352, (2018)

4. Á. Debreczeni, J. Molnár, R. Tompa: Opportunities of re-establishing underground mining in the Borsod coal basin in north-eastern Hungary. New Trends in Production Engineering. International Conference MINING TECHNIQUES ,TUR” 2019. Vol 2, Issue 1, p 532-540. (2019)

5. Á. Debreczeni, T. Havelda, J. Bombicz, T. Kaufmann, J. Verbóczi, R. Barczikayné Szeiler, Z. Püspöki: Kiemelt mélymüvelésü szénbányászati projektek földtani bányászati adottságai. A hazai szénvagyon és hasznosítási lehetőségei. Magyar Bányászati és Földtani Szolgálat. Budapest, p 8596 (2018)

6. Dubicsány kőszén előfordulás kitermelésének megvalósíthatósági vizsgálata, Inno-Favorem Kereskedelmi és Szolgáltató Bt. (2015) 